\title{
University teachers' technology integration in teaching English as a foreign language: evidence from a case study in mainland China
}

\author{
Weijun Liang ${ }^{1}$
}

Received: 29 May 2021 / Accepted: 26 July 2021 / Published online: 27 August 2021

(c) The Author(s), under exclusive licence to Springer Nature Switzerland AG 2021

\begin{abstract}
Despite the increasing use of technology in education, university teachers' perceptions and use of technology are under-explored, particularly in the context of English language classrooms in mainland China. To fill the research gap, this article reports the findings of a case study exploring university teachers' perceptions of and practices with technology as well as the challenges of technology implementation. To provide a microscopic understanding of these issues from teachers' perspective, an online survey was first distributed to all 60 English teachers at a focal university, with 35 valid surveys returned. Subsequently, nine survey respondents participated in in-depth follow-up interviews. The findings suggest that teachers used technology predominantly for teacher-centred purposes rather than for active student engagement although they had positive perceptions of technology integration. They also held critical viewpoints on the use of technology in English teaching. In addition, teachers perceived more external barriers to technology integration (e.g. insufficient technical and pedagogical training, "the Great Firewall") than internal challenges (e.g. students' lack of interest in technology). The study contributes to the understanding of university teachers' technology uptake and carries important implications for the promotion of teaching innovation and effectiveness in higher education contexts.
\end{abstract}

Keywords Challenges of technology implementation · English language teaching · Higher education · Patterns of technology use $\cdot$ Perceptions of technology integration

Weijun Liang

weijun15@connect.hku.hk

1 Faculty of Education, The University of Hong Kong, MW667, Meng Wah Complex, Pokfulam Road, Pokfulam, Hong Kong 


\section{Introduction}

The value of technology in language education has been discussed since the 1960s (Alahmari 2013), and the advancement of technology has brought about many changes and reforms in education (Delgado et al. 2015; DelliCarpini 2012; Huang et al. 2019). In our current fight against the coronavirus pandemic, computer assisted language learning (CALL) has played a particularly important role in education because of its various affordances for online teaching and learning. Research has shown that integrating technology into classroom settings can help stimulate questioning by students, facilitate interaction, encourage students' selfexpression, and enhance teaching productivity (Baydas and Goktas 2016; Wilson et al. 2018). Despite the benefits of educational technology, technology sceptics question the value of integrating technology into the classroom. From their conservative perspective, computers may reduce the wide variety of teaching and learning to simply rote learning and distract students' attention (Collins and Halverson 2018).

Regardless of the debate over the affordances of educational technology, using technology for instructional purposes has become increasingly popular around the world (Kulavuz-Onal 2018). Against this backdrop, China's education authorities promote the use of technology in education, particularly in foreign language education ( $\mathrm{Li}$ and $\mathrm{Ni}$ 2011). English as a Foreign Language (EFL) teachers are encouraged to integrate audio and video materials, online resources, emerging multimedia software, and generally CALL into the classroom (Department of Education in China 2001, as cited in Li and Ni 2011). However, teachers do not use technology to its full potential (DelliCarpini 2012), and their employment of educational technology lags far behind the availability of technology for teaching (Hedayati and Marandi 2014; Kopcha 2012; Moore et al. 1998). In order to address this perennial problem of "high access, low use" (Li and Ni 2011, p. 72) and to facilitate teachers' technology integration, it is particularly important to understand their perceptions and use of technology (Ertmer et al. 2012).

By exploring university EFL teachers' perceptions and use of technology, the study reported herein seeks to address two important knowledge gaps. First, the study constitutes a significant addition to the scant literature on university EFL teachers' technology implementation and their opinions regarding technology integration (Teo et al. 2018). Specifically, this study aims to examine the types of technologies teachers use in their English teaching and the ways they employ the technologies. The rationale is that even when teachers integrate technology on a regular basis, it remains uncertain whether or not they use it in a transformative manner (Ding et al. 2019). Since teachers' technology use is arguably related to their perceptions (Judson 2006; Li and Ni 2011), this study also probes their opinions and thoughts on technology integration, with a view to examining whether their perceptions are aligned with their practices. Furthermore, the study examined teachers' perceived barriers to technology implementation, which is crucial for addressing the challenges of technology implementation and yielding insights into how the potential of educational technology can be maximised. Although 
this study was situated in the local context of mainland China, the issues it aimed to address bear a remarkable resemblance to those in other regions and societies. Around the globe, technology has been increasingly adopted in higher education to facilitate online teaching and learning, particularly during the pandemic. This calls for more empirical understanding of university instructors' perceptions and use of technology and the challenges they encounter. Such an understanding of these significant problems would enable policy makers and university administration to make informed decisions about how to deploy various resources to support teachers' use of technology in the classroom, with the ultimate goal of improving teaching and learning quality.

The second knowledge gap this study attempts to address is that whilst the majority of previous studies rely on either qualitative or quantitative data to investigate teachers' perceptions and practices (e.g. Aydin 2013; Celik 2013; Li 2014; Sağlam and Sert 2012), limited research takes advantage of both types of data. The present study therefore reports both qualitative (i.e. interview data) and quantitative (i.e. survey data) findings with a view to providing a holistic and nuanced understanding of teachers' technology uptake and their perspectives. This could help to generate novel findings regarding the important topic of technology integration which has great relevance to the international scholars and educational practitioners. In this regard, the current findings not only corroborate those of previous research but also advance our understanding of university EFL teachers' perceptions and use of technology, yielding significant implications for technology integration in higher education in many parts of the world. In the light of the knowledge gaps, the present study seeks to address the following research questions:

(1) What type(s) of technology did university EFL teachers in mainland China use and for what purposes?

(2) What were their perceptions of using technology in English teaching?

(3) What challenges and constraints did they perceive in technology implementation?

\section{Literature review}

In accordance with the aims of this study expounded above, the Literature Review section comprises three sub-sections: (1) English teachers' use of technology, (2) English teachers' perceptions of technology use, and (3) challenges of technology integration into English classrooms. This section fleshes out the abovementioned research gaps whilst providing a conceptual framework for the interpretation of the research findings reported later.

\section{English teachers' use of technology}

Technology is defined broadly in this article as "traditional or established technologies" (e.g. computers, emails, mobile phones) and "new and emerging technologies" 
(e.g. wikis, podcasts and other Web 2.0 technologies) (Waycott et al. 2010, p. 1203) as well as other technologies that have the potential to promote teaching and learning. Technology integration is defined as "the degree to which technology is used to facilitate teaching and learning" (Ertmer 1999, p. 50, as cited in Torsani 2016). In other words, technology integration is not simply about using technology in the classroom. Instead, integration can be achieved only when technology is used effectively to support teaching and learning. One main principle for technology integration is therefore to fulfil pedagogical goals and address instructional problems and to regard educational technology as an integral part of the teaching process (Okojie et al. 2006). It is also pivotal for teachers to contemplate the intricate relationship between technology use and pedagogy, which is crucial for their success in technology integration. They should be well versed in using pedagogical principles to guide their use of technology for instructional purposes (Okojie et al., 2006).

Research has shown that English teachers frequently utilise word processors (Meskill et al. 2006), PowerPoint (Li 2014), and other traditional technologies (Trace et al. 2018; Yang and Huang 2008). On a less frequent basis, however, teachers use new and emerging technologies such as Second Life and Rosetta Stone (Celik 2013). Whilst such empirical findings are derived from either surveys (e.g. Celik 2013; Meskill et al. 2006) or interviews (e.g. Li 2014), few studies rely on both quantitative and qualitative data to investigate teachers' technology uptake with both breadth and depth. In addition, the extant scholarship has largely focused on in-service primary and secondary school teachers (e.g. Celik 2013; Li 2014; Meskill et al. 2006) and pre-service teachers (e.g. Sang et al. 2011); less is known about university teachers' technology integration, particularly in the context of Chinese EFL classrooms (Teo et al. 2018).

In terms of the purposes of teachers' technology use, the literature suggests that they implement technology in the classroom mainly for teacher-centred purposes ( $\mathrm{Li}$ et al. 2019), such as delivering and presenting information to students (Wozney et al. 2006), preparing teaching materials (England 2007; Yang and Huang 2008), and dealing with classroom management issues ( $\mathrm{Li}$ and Ni 2011). On the other hand, teachers tend not to use technology in a student-centred manner, such as for recreation (e.g. games) and expansive purposes (e.g. simulations) (Wozney et al. 2006) as well as for constructivist learning (e.g. engaging students in creating digital artefacts to demonstrate their learning) (Gurcay et al. 2013). More worryingly, teachers rarely use multimodal technology to provide students with generative and meaningful learning experiences (Siefert et al. 2019). They even fail to use technology to create a communicative language learning environment for students ( $\mathrm{Li}$ et al. 2019). Teachers' use of technology is retrained probably because of their traditional transmissive beliefs (Liu et al. 2017). The literature thus calls for more student-centred use of technology which employs generative and collaborative approaches (Siefert et al. 2019), although research also suggests that teachers hold more constructivistoriented pedagogical beliefs than the transmissive-oriented ones (Liu, et al. 2017).

Similar to the problems with the literature on the types of technologies English teachers apply, it seems that the studies on how teachers use technology are mainly conducted in primary and secondary school settings. In particular, such studies fail to explain why the use of technology for teacher-centred activities dominates in the 
classroom. This is probably because the research relies only on teachers' self-report survey data (e.g. Li and Ni 2011; Wozney et al. 2006) without probing their actual classroom practices with technology through interviews. Even when interviews are used to interrogate teachers' technology integration (e.g. Siefert et al. 2019), this type of research does not attempt to explain why the use of technology is predominantly for teacher-centred purposes. Therefore, further research using both survey and interview data is needed to shed some light on this issue.

\section{English teachers' perceptions of technology use}

Whilst some studies have suggested that there is a parallel between teachers' perceptions of technology use and their classroom practices (Ding et al. 2019; Türel and Johnson 2012; Van Praag and Sanchez 2015), other studies have revealed a misalignment between teachers' attitudes towards technology integration and their technology use (England 2007; Judson 2006; Li and Ni 2011). In other words, teachers' perceptions of using technology in classroom teaching can be congruous or incongruous with their actual practices. Looking specifically at teachers' perceptions, the majority of empirical findings indicate that EFL teachers have positive perceptions of technology use in the classroom (e.g. Aydin 2013; Canals and Al-Rawashdeh 2019; Huang et al. 2019; Morgana and Shrestha 2018; O’Bryan and Hegelehimer 2007; Thang et al. 2014). They hold positive attitudes towards CALL and using ICT in education (Albirini 2006; Chen et al. 2019; Fatemi Jahromi and Salimi 2013; Kuru Gönen 2019; Taghizadeh and Hasani Yourdshahi 2019; Yunus 2007), and such attitudes are related to teachers' perceived usefulness of technology (England 2007; Hsu 2016; Sun and Mei 2020; Trace et al. 2018). For instance, they perceive technology to improve teaching efficiency and enhance student learning and interaction (Hsieh and Tsai 2017; Van Olphen 2013) and improve students' receptive skills such as listening and reading (Canals and Al-Rawashdeh 2019). In particular, teachers positively perceive the usefulness of vlogs in enhancing students' listening and vocabulary learning (Aldukhayel 2019). They also believe the use of smartphones in the classroom to enhance students' motivation and creativity (Alzubi 2019). Most recently, teachers are found to perceive that students learn at the same rate or even faster in an online virtual classroom than in a traditional one (Manegre and Sabiri 2020). In addition, teachers feel that technology provides them with a broad range of authentic teaching resources (Jeong 2017) and help them adjust their lessons according to students' needs (Kuru Gönen 2019).

However, despite the perceived benefits of technology adoption, some studies reveal teachers to hold negative attitudes towards the value of technology in English teaching (e.g. Li 2007; Van Praag and Sanchez 2015; Yang and Huang 2008). They even perceive technology integration to increase their workloads (Hedayati and Marandi 2014; Raman and Yamat 2014), bring about technical issues (Bueno Alastuey 2011; Comas-Quinn 2011), and reduce face-to-face interaction (Waycott et al. 2010). In particular, teachers perceive the use of webcam in online language lessons to be tiring and intrusive, causing privacy concerns (Kozar 2016). They also consider the use of mobile devices in the classroom invasive in the sense that the 
devices challenge the traditional classroom hierarchy (Van Praag \& Sanchez 2015). Mobile technology can also be distractive and disengaging when students use it for non-pedagogical purposes such as updating social media sites (Van Praag and Sanchez 2015).

Since the extant literature suggests that teachers have both positive and negative perceptions of technology integration and perceive various benefits and drawbacks of using technology in the classroom, it is not surprising that some teachers hold a critical, balanced viewpoint regarding whether or not technology is beneficial to their teaching. For instance, they believe technology to be a "double-edged sword" requiring the judgement of its value to be based on specific conditions and contexts (Allam and Elyas 2016; Liu and Chao 2018). From teachers' perspective, the use of technology should be underpinned by pedagogical theories and principles to maximise the potential of educational technology (Koçoğlu 2009). Such critical reflection on the use of technology can help teachers engage with the ever-changing technology in a reflective manner (Chao 2015).

A large number of empirical research has investigated teachers' perceptions of technology use through questionnaires and interviews. For instance, Aydin (2013) conducted a background questionnaire survey with 157 EFL teachers to assess their attitudes toward and perceived self-efficacy in integrating computers into their teaching. Also using questionnaires as a means of probing respondents' perceptions of technology use, Canals and Al-Rawashdeh (2019) concluded that teachers perceived more benefits of using technology for acquisition of listening and reading skills than for speaking and writing skills. As for interviews, Huang et al. (2019) carried out semi-structured, in-depth interviews with 14 university teachers in China, revealing the teachers' positive perceptions of technology use in teaching. Similarly, in Van Praag and Sanchez's (2015) study, semi-structured interviews were used to explore teachers' perceptions of their use of mobile devices in second language teaching. Since the literature review suggests that both questionnaires and interviews are viable means of examining research participations' perceptions of technology use, the current study adopted both data collection methods to explore this issue.

\section{Challenges of technology integration into English classrooms}

The literature has classified the challenges of integrating technology into English teaching into external (e.g. training and support) and internal ones (e.g. attitudes and beliefs) (Johnson et al. 2016). A more specific classification categorises the challenges into four types: material and finance, school-specific factors, human, and support (van Braak 2001). First, concerning material and finance, limited access to computers is often cited as one of the main constraints for K-12 teachers in the USA, Egypt, Iran and Malaysia (Chiero 1997; England 2007; Taghizadeh and Hasani Yourdshahi 2019; Yunus 2007). Similarly, availability of technological resources is reported as one important factor influencing secondary school teachers' technology integration in China ( $\mathrm{Li} 2014$ ) and technology use in English language teacher education in Turkey, Poland and Portugal (Aşık et al. 2019). In addition, lack of administrative facilities constitutes one major barrier to technology implementation 
for EFL university instructors in Iran (Ashrafzadeh and Sayadian 2015). It therefore seems that the challenge of material and finance is a common issue for different levels of education in different parts of the world.

Regarding the second type of challenge, namely school-specific factors, the most frequently reported issue is time constraint in school schedules (e.g. Bauer and Kenton 2005; Comas-Quinn 2011; Pelgrum 2001; Singh 2019). For instance, based on semi-structured interviews with ten English teachers, Singh (2019) reports the normal length of class duration (i.e. 40 to $45 \mathrm{~min}$ ) to be insufficient for technology implementation. Teachers do not have sufficient time to use computer skills (Yunus 2007). In addition, the design of school curriculum and assessment also plays a significant role in teachers' technology implementation (England 2007; Gruba and Chau Nguyen 2019).

In terms of human factors, teachers' beliefs and willingness to accept technology have been identified as one of the most significant factors in technology integration (Mumtaz 2000; Thang et al. 2014; Van Praag and Sanchez 2015). In addition, lack of insights into the possibilities and potential of educational technology is regarded as an important constraint on technology integration (Blake 2007; Comas-Quinn 2011; van Braak 2001). Students' low digital literacy is also reported as a prominent challenge for teachers' technology integration (Gruba and Chau Nguyen 2019).

Lastly, with regard to support, the literature highlights professional training and technical support (England 2007; Gruba and Chau Nguyen 2019; Hedayati and Marandi 2014; Taghizadeh and Hasani Yourdshahi 2019; Yunus 2007), hardware support and management (Yang and Huang 2008), instructional support (Aydin 2013), and support from school principals and institutes (Aşı et al. 2019; Hedayati and Marandi 2014; Li 2014; Taghizadeh and Hasani Yourdshahi 2019). These kinds of support are deemed crucial factors in technology adoption.

Although research has identified various inhibitors of technology implementation, the challenges for university EFL instructors are under-researched, particularly in the Asian context (Ashrafzadeh and Sayadian 2015). To fill this knowledge gap, this study not only examined university teachers' perceptions and use of technology, but also explored the challenges facing their technology integration.

\section{Research design, setting and participants}

This study employed a single-case study design, as it aimed to capture university EFL teachers' experiences and perceptions of using technology in the classroom. Accommodating both qualitative and quantitative methods, case study allows an in-depth understanding of a specific phenomenon (Yin 2009). In this study, one university was regarded as one case. The university was a provincial key university $^{1}$ in southeast China. One case was selected because focusing on one representative university helps to yield in-depth understanding of the phenomenon

\footnotetext{
1 Universities in mainland China are classified into key and non-key universities based on such factors as their academic strength and management capacity (Wang 2009).
} 
Table 1 Demographic backgrounds of survey participants $(\mathrm{N}=35)$

\begin{tabular}{|c|c|c|}
\hline Categories & Frequency & $\%$ \\
\hline \multicolumn{3}{|l|}{ Gender } \\
\hline Male & 15 & 42.9 \\
\hline Female & 20 & 57.1 \\
\hline \multicolumn{3}{|l|}{ Age } \\
\hline 25 or younger & 2 & 5.7 \\
\hline 26 to 35 & 19 & 54.3 \\
\hline 36 to 45 & 5 & 14.3 \\
\hline 46 or older & 9 & 25.7 \\
\hline \multicolumn{3}{|l|}{ Degree } \\
\hline Bachelor & 2 & 5.7 \\
\hline Master & 30 & 85.7 \\
\hline $\mathrm{PhD}$ & 3 & 8.6 \\
\hline \multicolumn{3}{|c|}{$\begin{array}{l}\text { Years of English teaching } \\
\text { experience }\end{array}$} \\
\hline $1-5$ & 18 & 51.4 \\
\hline $6-10$ & 7 & 20.0 \\
\hline $11-15$ & 5 & 14.3 \\
\hline 16 or more & 5 & 14.3 \\
\hline \multicolumn{3}{|c|}{$\begin{array}{l}\text { Participation in training in } \\
\text { technology integration }\end{array}$} \\
\hline Yes & 34 & 97.1 \\
\hline No & 1 & 2.9 \\
\hline
\end{tabular}

of technology integration whilst shedding light on the situation at other similar universities (Hu and McGrath 2011). This case university was representative and selected for the following reasons. First, it is investing considerably in building a technology-enhanced learning environment and encouraging university-wide technology implementation. It is therefore representative of universities in mainland China that are implementing technology-related educational policies such as the "ten-year development plan for education informatisation (2011-2020)" which stipulates the integration of technology into teaching and learning and facility investment (Huang et al. 2019). Second, at the case university, English is taught as a foreign language and is a compulsory subject for all undergraduate students. In addition, the university has an English Language Centre providing different levels of English for Academic Purposes courses to all non-Englishmajor students. These conditions are typical of those in many key universities around mainland China (Wette and Barkhuizen 2009).

The teacher participants of this study were recruited from the English Language Centre at the focal university. At the time of this study, the Centre had a total of 60 teachers, and approximately half of them are from countries outside China. An online survey was distributed to all the 60 teachers, with 35 of them returning the survey. In addition, nine survey participants who expressed their willingness to provide further support participated in individual follow-up interviews. Tables 1 and 2 
Table 2 Background information of interview participants $(\mathrm{N}=9)$

\begin{tabular}{|c|c|c|c|c|c|c|}
\hline Teachers & Gender & Age & Nationality & Degree & $\begin{array}{l}\text { Years of English } \\
\text { teaching experi- } \\
\text { ence }\end{array}$ & $\begin{array}{l}\text { Participation in training } \\
\text { in technology integra- } \\
\text { tion }\end{array}$ \\
\hline $\mathrm{T} 1$ & Male & 26 to 35 & Chinese & Master & $1-5$ & Yes \\
\hline $\mathrm{T} 2$ & Female & 26 to 35 & Chinese & Master & $1-5$ & Yes \\
\hline T3 & Female & 26 to 35 & Chinese & Master & $1-5$ & Yes \\
\hline $\mathrm{T} 4$ & Male & 26 to 35 & Chinese & $\mathrm{PhD}$ & $6-10$ & Yes \\
\hline T5 & Male & 46 or older & American & Master & 16 or more & Yes \\
\hline T6 & Male & 26 to 35 & American & Master & $1-5$ & Yes \\
\hline $\mathrm{T} 7$ & Female & 46 or older & American & Master & $1-5$ & Yes \\
\hline $\mathrm{T} 8$ & Female & 26 to 35 & Chinese & Master & $6-10$ & Yes \\
\hline T9 & Female & 25 or younger & Chinese & Master & $1-5$ & Yes \\
\hline
\end{tabular}

below show the background information of the survey and interview participants, respectively.

\section{Online survey}

To provide a general picture of teachers' technology use, perceptions, and the challenges facing their technology implementation, an online survey (see Appendix A) was used to collect quantitative data. The survey consisted of four sections. Section 1 required participants to provide such demographic information as gender, age, degree, and years of English teaching experience. Section 2 contained 11 items about the frequency of technology use, and the items were measured on a 5-point Likert scale, ranging from $1=$ Never to $5=$ almost every day. Section 3 included 10 statements eliciting participants' perceptions of technology use in English teaching, and amongst the statements seven were positively phrased whilst three were negatively phrased. For the seven positive statements (e.g. "I believe that students enjoy using technology in the classroom"), they were measured on a 5-point Likert scale, ranging from $1=$ strongly disagree to $5=$ strongly agree. On the contrary, for the three negative statements (e.g. "I think that using technology to facilitate teaching will be boring for my students"), they were measured on a 5-point Likert, ranging from $1=$ strongly agree to $5=$ strongly disagree. Similarly, since Sect. 4 comprised 15 items of the challenges of technology implementation, the items were measured on a 5-point Likert scale, ranging from $1=$ strongly agree to $5=$ strongly disagree .

The survey was developed based on previous established research on EFL teachers' engagement with technology (Alahmari 2013) and factors influencing the use of technology in the classroom (van Braak 2001). The instruments employed by Alahmari (2013) and van Braak (2001) have been validated by empirical research. Therefore, it seems rather reasonable to adapt them for the current study, although they have not been used in the Chinese context. To enhance their suitability for the current research setting, the adaptation was based on a pilot study which aimed to: 
(1) improve the appropriateness and clarity of the statements in the survey by gaining feedback from pilot study participants $(N=11)$, and $(2)$ obtain data to test the validity and reliability of the survey. Based on the feedback from the pilot study participants, the researcher made two major modifications to the survey: (1) adding a definition of "technology" to ensure the consistency of respondents' understanding of technology, and (2) adding three items of technologies (i.e. items i, j, k in Sect. 2 of the survey) because the participants reported that they also used those technologies in their teaching. Such a refinement helped to reflect the rapid development of technology. Furthermore, in order to test the internal reliability of the survey, the researcher used SPSS to compute Cronbach's Alpha, and its value was found out as 0.83 and 0.86 for the scales of perceptions and challenges, respectively. Since the values were above 0.70 , they indicated good reliability (Cohen et al. 2013).

\section{Follow-up interviews}

Serving to triangulate the survey data and to gain a multifaceted answer to the research questions, the teacher interviews offered a direct viewpoint from the classroom and an in-depth understanding of teachers' perceptions and use of technology as well as the challenges they perceived. The development of the interview protocol (see Appendix B) was informed by previous studies on teachers' perceptions and use of technology in English language teaching (e.g. Alahmari 2013; Sağlam and Sert 2012; Sung and Yeh 2012). In the development process, particular attention was paid to refining the interview questions to fit the research context. Moreover, the interview protocol underwent ongoing development because upon completion of each interview the researcher reviewed the interview responses and refined the protocol by adding some prompts potentially relevant to other teacher interviewees. In other words, the interview with one teacher helped the researcher understand more about the university context and ask more relevant follow-up questions in the remaining interviews.

The interview comprised five guiding questions and was semi-structured in nature to allow participants to elaborate their thoughts and ideas and the researcher to ask follow-up questions. Since the interviews aimed to elicit further responses from survey participants, the follow-up questions were formulated also based on teachers' responses to the survey. All the interviews were conducted by the author in the participants' preferred languages (i.e. Chinese mandarin, Cantonese, or English) to avoid language difficulty and were audio-recorded for transcription purposes. The interviews lasted between 25 and $70 \mathrm{~min}$. Amongst the nine teacher interviewees, however, two of them (i.e. T4 and T5) only provided written responses to the interview questions because they felt more comfortable doing so. 


\section{Data analysis}

A total of 35 valid teacher surveys were entered into the SPSS database. Descriptive analysis was then utilised to provide analytical profiles of teachers' technology use, perceptions, and challenges. After all survey responses were given a specific value, the mean scores, frequencies, standard deviations of each survey item were computed.

The interview data were transcribed verbatim and sent back to the interviewees for respondent validation to ensure the quality of the transcription (Cohen et al. 2013). Only those transcript extracts selected for use were translated if they were not in English, and the translation was double-checked by a certified Chinese-English translator. The interview data were then subjected to thematic analysis given its great potential for identifying patterns of qualitative responses from different participants and yielding unanticipated insights (Braun and Clarke 2006). With the aid of NVivo, the researcher scrutinised the interview transcripts many times before conducting initial coding according to the research questions and the literature reviewed in this article. The initial coding was followed by an iterative process of coding and recoding, and descriptive codes were used to summarise the topic of data segments for subsequent indexing and categorising (Miles et al. 2014). Similar codes were then collapsed into provisional themes. For instance, descriptive codes such as "engaging and motivating" and "convenient and fast" were categorised into a provisional theme named "perceived benefits of technology" to reflect teachers' perceptions of technology integration. Continuous reflections were made to ensure that all provisional themes were closely related to the research questions and supported by rich data from different participants. Subsequently, the theme/sub-themes were compared and combined to form the main themes with reference to the conceptual framework explicated in the Literature Review section. Based on the main themes and the framework, the researcher then constructed analytic narrative of the data. To help safeguard the quality of data analysis, following Braun et al. (2016), the researcher employed a reflexive and deliberative approach during the data analysis process with a view to "capturing the messy, contradictory, and complex nature of psychological and social meanings" (Braun et al. 2016, p. 202).

It is noteworthy that the questionnaire data were interpreted along with the interview data during the process of data interpretation. Whilst the former depicted a general picture of teachers' technology use, perceptions, and the challenges facing their technology implementation, the latter was used to triangulate the former and to obtain a multifaceted answer to the research questions. The two sources of data combined to offer a holistic and nuanced understanding of the issues under investigation. The Findings section below therefore presents the two sources of data in an integrated manner.

\section{Findings}

This section is organised in accordance with the three research questions and therefore encompasses three sub-sections: (1) EFL teachers' use of technology, (2) perceptions of technology use, and (3) inhibitors of technology integration. Each 
sub-section presents the relevant survey and interview findings, and preliminary interpretations are provided with reference to the literature reviewed earlier.

\section{EFL teachers' use of technology}

Amongst the different technologies listed in Table 3, teacher respondents most frequently utilised Microsoft Word to create and edit text $(\mathrm{M}=4.66, \mathrm{SD}=0.64)$ and PowerPoint to make presentations $(\mathrm{M}=4.54, \mathrm{SD}=0.70)$. In particular, $71.4 \%$ of respondents used word processors daily, and $62.9 \%$ used PowerPoint daily. In addition, they frequently shared course materials via Moodle $(\mathrm{M}=4.34, \mathrm{SD}=0.64)$ and communicated with students via text (e.g. chat/discussion on WeChat, emails, forums on Moodle) $(\mathrm{M}=4.34, \mathrm{SD}=0.94)$. Such findings suggest that teachers mostly used traditional technologies (e.g. Microsoft Word and PowerPoint) to plan for and deliver instructions. For emerging technologies (e.g. WeChat), their use was limited to interaction with students.

Conversely, on a much less frequent basis, teachers applied technological applications such as SoJump and Kahoot! to design in-class quizzes $(\mathrm{M}=2.37, \mathrm{SD}=1.21)$ and utilised gaming tools (e.g. Second Life) to engage students in virtual worlds and simulations $(\mathrm{M}=1.54, \mathrm{SD}=1.04)$. It seems that teachers rarely implemented these relatively new and emerging technologies in the classroom to enhance students' learning experience. The above findings may imply that compared with emerging technologies, traditional technologies were more accessible and easier to apply in classroom teaching. On the other hand, teachers might be less familiar with emerging technologies and lacked the knowledge and skills to successfully integrate them into the English classroom (Taghizadeh and Hasani Yourdshahi 2019), which led to their less frequent use.

Echoing the survey findings whilst providing more insights, the interview data revealed teachers to mostly rely on traditional technologies to deliver and present information to students (Wozney et al. 2006). For instance, they routinely used PowerPoint, with one of them using it specifically to present students' common problems in writing and to make a mock exam for oral English. They used projectors to show students PowerPoint slides and other materials. They also used Microsoft Word to prepare course materials and provide feedback to students' writing. As for emerging technologies such as Moodle, the most common use by teachers was for logistics purposes, that is, they treated Moodle mainly as a database for uploading, storing and sharing course materials, although they also used the forum function of Moodle to discuss and interact with students and to promote critical discussion amongst students. In addition, they used Moodle to assign and collect homework, make appointments with students, grade students' homework, and design in-class quizzes. When it comes to WeChat, teachers reported that this social networking tool allowed them to communicate with students and send important messages. The interview data also indicated that teachers asked students to use mobile phones to record their oral English, use audio and visual materials to train students' listening and other language skills, and use Kahoot! to pose questions, design quizzes and help students revise course content. Teachers also introduced students to online 


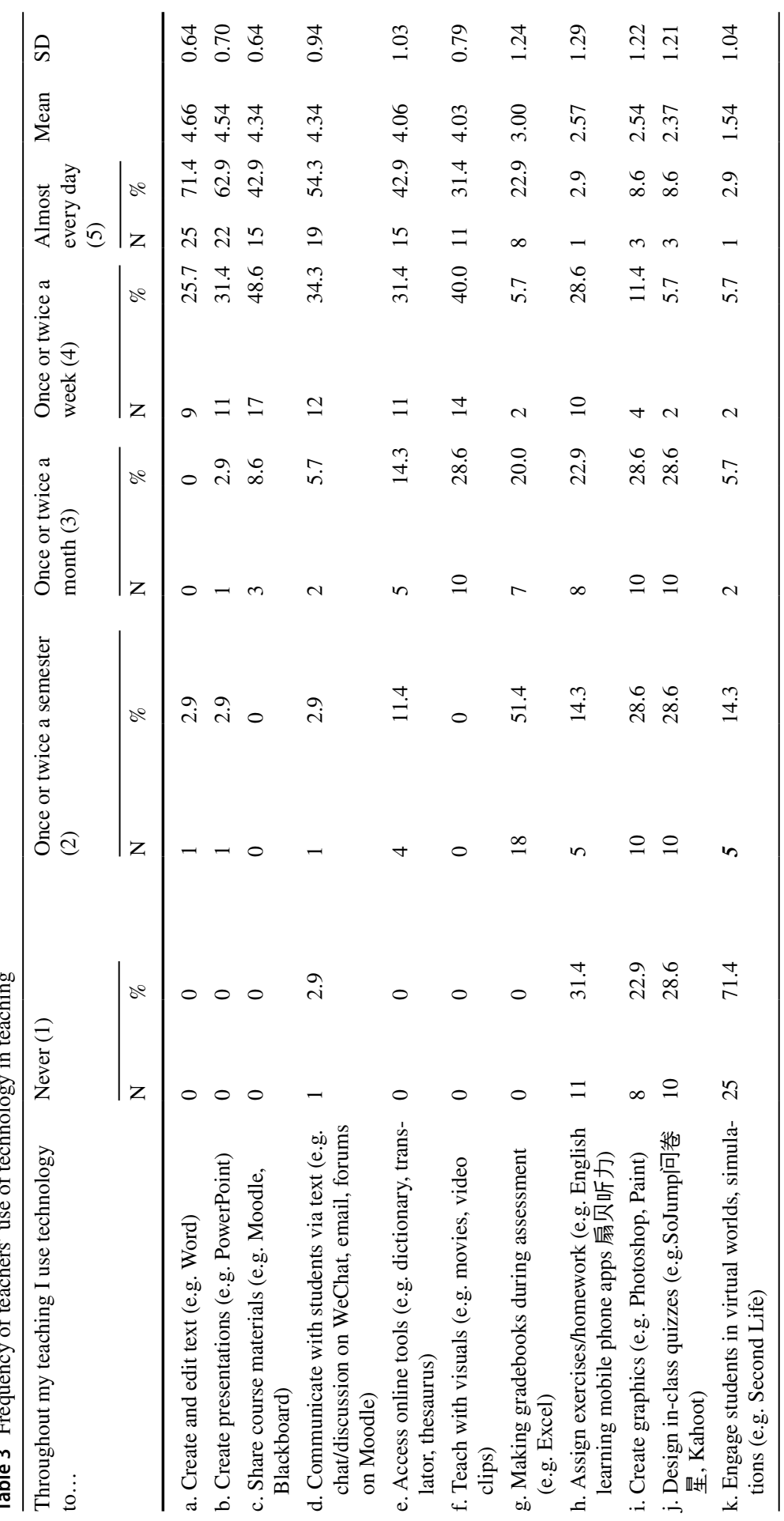


English learning resources for their self-study and used online teaching resources to supplement course materials.

It appears that teachers' use of both traditional and emerging technologies was primarily for teacher-centred purposes rather than student-centred purposes. In this regard, the interview data provide some insights into why teacher-centred use was more common. The reasons may relate to teachers' perception that teaching without the use of technology has its own advantages and therefore technology integration is not a must, as illustrated by the following illustrative quote:

All of our teachers tend to use traditional methods of teaching [...] because sometimes we think that the traditional methods do not require the use of any technology but only paper and pencil, which helps students to form a close relationship with each other. That means their interaction is more direct and better. Maybe this is one of the reasons why we do not use many technologies in teaching. The traditional teaching has its own merits. (T1)

In addition, teachers preferred to stick with traditional teaching without technology use probably because they did not see the potential and advantages of technology integration over traditional teaching:

If the technological platform is not innovative enough or functions similarly as traditional teaching, then I think it is very unlikely that technology can replace traditional stuff. The reason is that [for instance] if I can draw a mind map on A4 size paper, I do not think it is necessary for students to use that technological platform to do so. (T2)

\section{Perceptions of technology use}

As Table 4 shows, teachers generally held positive attitudes towards technology use in the classroom. Specifically, $82.8 \%$ of respondents strongly agreed or agreed that students enjoy using technology in the classroom (Statement 1) $(M=4.29$, $\mathrm{SD}=0.89) .88 .6 \%$ of respondents concurred with the importance of students' access to technology in every classroom (Statement 2$)(\mathrm{M}=4.26, \mathrm{SD}=0.74)$. It is noteworthy that whilst $54.3 \%$ of respondents strongly agreed or agreed that students will learn more if technology is used in the classroom (Statement 3) $(M=3.80$, $\mathrm{SD}=0.96), 40 \%$ of respondents neither agreed nor disagreed with this statement. They did not take a stance on this statement probably because they thought that the effect of technology on students' learning depends on different circumstances.

As Table 5 illustrates, on the contrary, $85.8 \%$ of teacher respondents strongly disagreed or disagreed that using technology to facilitate teaching will be boring for students $(\mathrm{M}=4.03, \mathrm{SD}=0.75) .68 .5 \%$ of respondents strongly disagreed or disagreed that they feel nervous about having to use technology in teaching $(M=3.91$, $\mathrm{SD}=0.98$ ). $80 \%$ of respondents strongly disagreed or disagreed that using technology in the classroom will interfere with their teaching $(\mathrm{M}=4.03, \mathrm{SD}=1.07)$. Their overall disagreement with the above negative statements also suggests that they had positive perceptions about technology integration. 


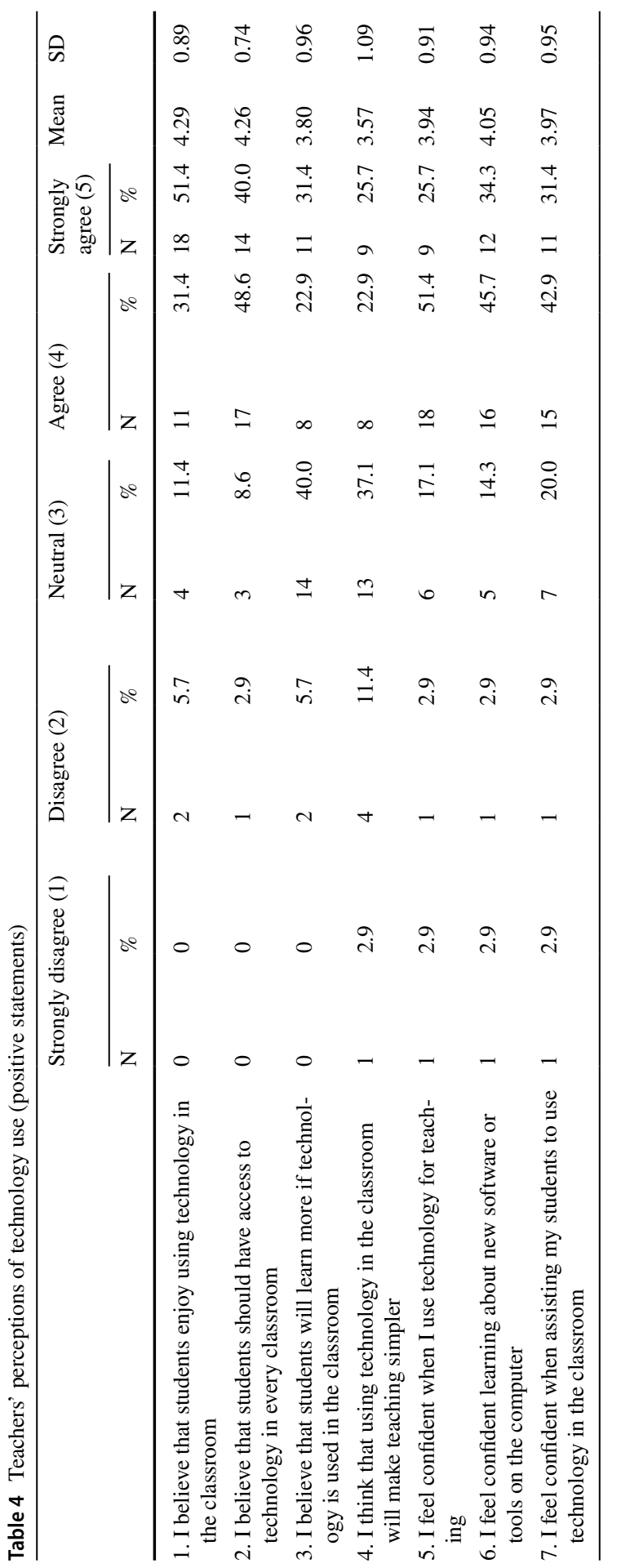




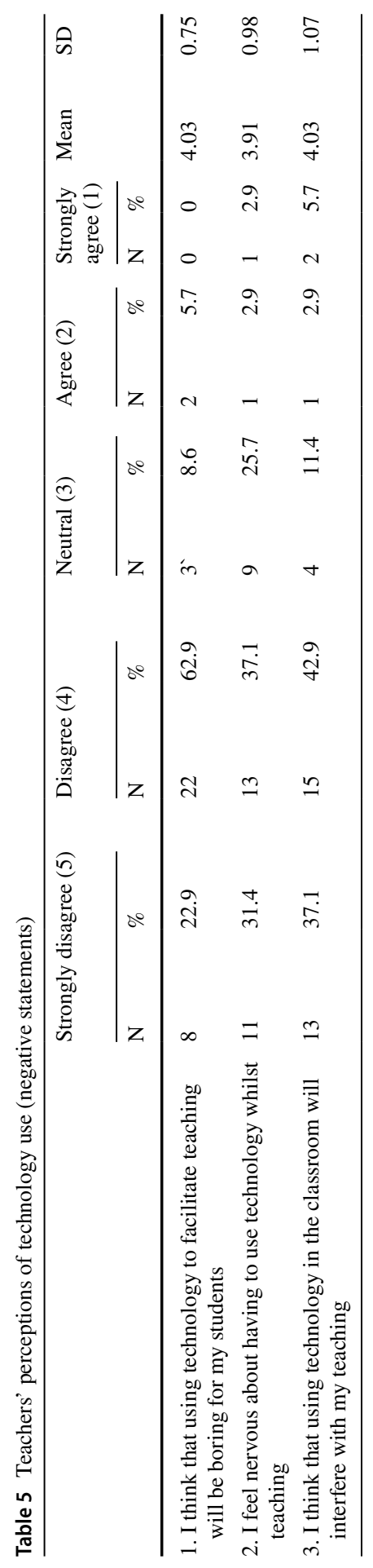


Whilst the above survey results provide a general picture of teachers' perceptions of technology use in the classroom, the interview findings allow a more indepth understanding of teachers' perceptions. Regarding teachers' perceived benefits of technology, they stated that technology provides them with a broad range of options and resources ( $\mathrm{Li}$ 2007). For instance, they felt that they can search and obtain extra teaching and learning materials to supplement those provided by textbooks. Similarly, they believed that mobile phones and Wi-Fi technology afford students easy access to online English learning resources. Students can readily find those materials that cater to their needs and practice their language skills through online reading and chatting. With the use of technology, teachers can also add more varieties of instructional approaches to their class, as illustrated by the following representative extracts:

One of the benefits, I guess, is that both teachers and students have more options in their classroom. They do not rely on the textbook only. Technology offers them more information and a more vivid channel for language learning and exposure. (T4)

Using technology can make our teaching different. For example, we can teach the same content with different types of technologies. (T1)

In addition, enhancing students' engagement and motivation is also one of the merits of technology frequently mentioned by teacher interviewees (Alzubi 2019). They believed that the use of technology adds new elements to their class and makes the class more interesting than the class without technology use. They even observed that some students become more interested in classroom activities when technology is used, especially in the first few times of its use. However, when technology is used too often, its novelty wears off and students become less motivated:

I found that technology use can attract students' attention. Moreover, some students may not be very interested in other activities. But once they use technology, they become very motivated. [...] and they especially enjoy technology when they use it for the first and second times. (T9)

Another prominent benefit identified by teachers is that technology provides great convenience to their teaching (Chang et al. 2012). For instance, since the materials they upload to Moodle for one class can be readily transferred to a new class, they do not need to upload the materials again when teaching a new class. They can also easily share the materials with other teachers using Moodle. Moreover, they do not need to print out the course materials before each class. Instead, students can download them by themselves from Moodle and print them when necessary. In addition, teachers also mentioned that WeChat provides them with an instant and convenient manner to contact students:

In fact, because students use WeChat more often, we can get their reply quickly. But that is not the case for emails since they do not check emails 
often. But they use WeChat every day, so WeChat is actually more convenient. (T9)

Time-saving and improved efficiency are also a frequently reported benefit of technology adoption (Hsieh and Tsai 2017). This is because teachers perceived that PowerPoint saves them the trouble of writing the same things on the blackboard for each class. They also stated that the Internet provides abundant off-theshelf audio and visual materials for their selection and use. However, they also realised that to let technology save time, they need to fully grasp how to use it first and familiarise students with it:

I think technology improves efficiency a lot. For example, we can prepare PPT slides before each class, so that we do not have to waste time writing on the blackboard in the class. (T8)

Once you know how to use technology, it is easy to use it. After all it will take time to learn, but once you know it and your students are familiar with it, it would be fine. (T6)

On the one hand, teachers appreciated the abovementioned benefits of technology. On the other hand, they pointed out the drawbacks of technology. The disadvantage most frequently mentioned is that students get distracted when using technology (Yunus et al. 2012). In particular, the use of mobile phones can direct students' attention to other interesting matters irrelevant to the class (Van Praag and Sanchez 2015), which may exert a negative influence on their learning:

You know students these days are addicted to smart phones. Well, they can be addicted to their smart phones. You have to be careful about their checking of WeChat messages. (T6)

The teachers also opined that the use of technology can be time-consuming under some circumstances (England 2007; Hedayati and Marandi 2014; Raman and Yamat 2014). For instance, when the Internet connection is unstable, students need more time to get access to the Internet. When students use a particular technological tool for the first time, it takes time to give them clear instructions and familiarise them with the given tool. It is interesting to note that sometimes students may spend more time figuring out how to use technology than using technology to improve their English:

Some software really takes time. [...] You need to take into account the time students need to spend, so I think some software is not very helpful but more time-consuming. Students spend their time on things that are not necessary.

Whilst the teacher informants were cognisant of both the advantages and disadvantages of technology, in general, they held positive attitudes towards technology use and believed that technology use is a trend and will be a norm in the future (Huang et al. 2019). Meanwhile, they thought critically about the use of technology in English teaching, arguing that whether technology plays a positive role in English 
Table 6 Constraints on technology implementation

\begin{tabular}{llll}
\hline $\begin{array}{l}\text { In my technology integration I perceive such con- } \\
\text { straints as... }\end{array}$ & Mean & SD & $\begin{array}{l}\text { Percentage of agreement } \\
\text { (strongly agree or agree) }\end{array}$ \\
\hline (a) Insufficient time & 2.26 & 1.02 & 64.7 \\
(b) Poor management/repair of classroom computers & 2.35 & 1.12 & 61.8 \\
(c) Unsuitable educational software & 2.38 & 0.92 & 61.8 \\
(d) Lack of possibilities for (in-service) training & 2.44 & 1.05 & 58.8 \\
(e) Students get distracted by the use of mobile & 2.56 & 1.19 & 55.9 \\
phones in class & & & \\
(f) Lack of equipment & 2.62 & 1.23 & 47.1 \\
(g) Lack of financial resources & 2.62 & 1.1 & 47.1 \\
(h) Inappropriate online teaching materials & 2.65 & 0.88 & 50 \\
(i) Lack of external support & 2.71 & 1.06 & 47.1 \\
(j) Lack of flexibility of the curriculum & 2.79 & 1.17 & 47.1 \\
(k) Insufficient insight in the possibilities of educa- & 2.82 & 0.97 & 38.2 \\
tional technology & & & \\
(l) Lack of interest in technology amongst the staff & 2.85 & 1.13 & 41.2 \\
(m) Lack of support from other staff members & 2.97 & 1.22 & 35.3 \\
(n) Negative attitude of school leaders & 3.12 & 1.09 & 23.5 \\
(o) Lack of interest amongst students & 3.85 & 0.86 & 2.9 \\
\hline
\end{tabular}

teaching largely depends on how it is used and under what conditions, which confirmed the relevant survey findings. Teachers also perceived that although technology can be used in a way that benefits teaching and learning, its use should be cautious and rational. It is unwise to rely heavily on technology as sometimes traditional teaching may be more effective. On the other hand, it is more important to consider how technology can be integrated into lesson plans to serve teaching and learning:

I think technology is an aid and it should not dominate teaching. We should not depend too much on it because sometimes it is necessary to consider its role in teaching and how to use it reasonably. We should not use technology just for its own sake, and the important thing is to combine it with the course content and syllabus. (T3)

\section{Inhibitors of technology integration}

As Table 6 indicates, the inhibitors mostly perceived by teachers can be subsumed under the category of "material and finance" (van Braak 2001) or the category of "external barriers" (Johnson et al. 2016). Specifically, the major barriers include insufficient time ( $\mathrm{M}=2.26, \mathrm{SD}=1.02,64.7 \%$ of agreement), poor management or repair of classroom computers $(\mathrm{M}=2.35, \mathrm{SD}=1.12,61.8 \%$ of agreement), unsuitable educational software $(\mathrm{M}=2.38, \mathrm{SD}=0.92,61.8 \%$ of agreement $)$, lack of possibilities for (in-service) training ( $\mathrm{M}=2.44, \mathrm{SD}=1.05,58.8 \%$ of agreement), and 
students being distracted by the use of mobile phones $(\mathrm{M}=2.56, \mathrm{SD}=1.19,55.9 \%$ of agreement).

As for the least perceived obstacles, only $2.9 \%$ of teachers strongly agreed or agreed that there was a lack of interest in technology amongst students $(M=3.85$, $\mathrm{SD}=0.86$ ). Only $23.5 \%$ of respondents concurred with the obstacle of negative attitudes of school leaders $(M=3.12, \mathrm{SD}=1.09)$. It therefore seems that human factors (van Braak 2001) were not a major challenge of technology implementation in this study.

With respect to the interview findings, they are generally in alignment with the above survey results whilst providing a deeper understanding of the challenges for teachers. In particular, teachers highlighted the barrier of "the Great Firewall", an Internet censorship system in mainland China blocking many English-medium websites and resources (Mei et al. 2018). This constraint prohibited teachers' access to many quality teaching resources and tools, which may have particular adverse effects on English teaching since they thought English teaching materials produced by English-speaking countries are often richer. Although teachers tried to overcome this barrier using a virtual private network (VPN), most of the time they found the VPN connection to be unstable and slow especially on campus:

In mainland China there are many things I can't get them involved in. They can't google subjects which would be really nice and they can't watch a lot of English videos that I would like them to catch. [...] Well, the biggest constraint of course is the Great Firewall in China. (T7)

The teachers also complained about the slow Internet speed and unstable Internet connection especially in the classroom (Cheok and Wong 2016; Hedayati and Marandi 2014). This concern deterred them from relying on the Internet when teaching in the classroom. Consequently, they prepared and downloaded the teaching materials before coming to class:

With a stronger Internet connection, I would be happy to use the Internet in the classroom. For now, however, it's just too risky to plan a lesson that depends on the Internet. (T5)

What exacerbated the problem was that both teachers and students had limited data for Internet connection, meaning that once they used up their data quota, they could not have access to the Internet unless they applied for more. This led some teachers to borrow data from their colleagues. Teachers found it ridiculous to have data limit because that limit was a great barrier for their searching for more teaching materials and updating of computer software:

For instance, when some teachers update their computer systems and download software, suddenly they run out of their data quota and complain in our WeChat group. Then they need to apply for more data from the Network Centre [of the university]. After they get extra data, they need to update the systems and download software again, so what is the point of setting the data limit? (T2) 
Another major constraint pointed out by teachers is concerned with the inconsistency of technological facilities across the classrooms. The fact that some classrooms are equipped with interactive whiteboards whilst others only have traditional blackboards caused uncertainty for teachers when deciding whether to use interactive whiteboards in their teaching. Before they teach in the classrooms, they do not know whether the classrooms assigned to them are equipped with interactive whiteboards.

Teachers also complained about the lack of technical and pedagogical training in technology use (Taghizadeh and Hasani Yourdshahi 2019). They did not have enough workshops that could help them learn how to use technology and integrate them into their teaching. For those workshops they attended, they found them not very useful because they were for a general audience but not tailor-made for English teachers:

The university gathers teachers teaching different courses from different departments and introduces them to some software. In fact, many times I think there is no need for me to participate in this kind of training because I won't use what they introduce. Such training is not targeted to a particular audience. (T2)

\section{Discussion and implications}

In response to the first research question regarding the types of technology university EFL teachers in China used and the purposes, a synthesis of the survey and interview data suggests that consistent with previous research findings (e.g. Polly and Rock 2016), teachers commonly used traditional technologies (e.g. Microsoft Word, PowerPoint, projectors) to prepare course materials and deliver instruction. They also adopted audio and visual materials as well as online teaching and learning resources to support students' learning in and outside of class. For emerging technologies (e.g. Moodle, WeChat), their use by teachers was predominately for logistics and social purposes (e.g. share course materials and communicate with students), although a few teachers used Moodle as a pedagogical tool to engage students in online discussion and used Kahoot! for evaluative purposes. These findings generally echo those of Tondeur et al. (2017) indicating that teachers employed a broad range of technological applications primarily for structured teaching and learning rather than active student engagement. Such findings are significant for international scholars and educational practitioners. The reason is that if they come to realise that teachers' technology integration is mainly at the surface level (i.e. serving structured teaching and learning), they may be prompted to think about effective ways of guiding teachers to use technology for student-centred activities to enhance student engagement.

In addition, the current findings suggest that teachers' technology use was mainly for informative and expressive purposes whilst there was a lack of use for more complex purposes such as for creative and expansive use, which echoes the findings from other regions and countries (e.g. Wozney et al. 2006). It therefore seems 
that most teachers failed to truly integrate technology into their classroom to create a student-centred learning environment in which students actively engage in learning with teachers serving as a facilitator (Gao et al. 2011; Johnson et al. 2016). Such findings imply that the potential of educational technology to enhance students' learning experience may not be fully achieved by teachers because they tend to use technology as an instructional delivery tool, but seldom apply technology as students' learning tools. In order to take full advantages of technology, teachers need to experience a paradigm shift from teacher-oriented to student-oriented (Bitner and Bitner 2002; Chen et al. 2019) and "from traditional transmissive pedagogy to constructivist pedagogy" (Liu et al. 2017, p. 758). They also need to understand the inherent value of technology integration because this will help them implement technology in a meaningful, student-centred manner (Vongkulluksn et al. 2017). In this sense, the current findings have great relevance to the global audience because the issue of not using technology for student-centred purposes has also been reported elsewhere and is yet to be resolved. Moreover, the findings suggest that the teachers were more familiar with the advantages of traditional teaching than those of technology integration, which may explain why their technology use was mainly teachercentred. Based on the findings of this study, it is suggested that to help teachers use technology in the classroom to create opportunities for student-centred learning, it is imperative that they transform their teaching beliefs from traditional to constructivist. This is because research (e.g. Hermans et al. 2008) has indicated that the more traditional teachers' beliefs are, the less likely that they will integrate technology in the classroom. Therefore, more efforts should be made in the field of teacher education in which a student-oriented mindset should be highly valued and prioritised. It is also crucial to provide teacher professional development programmes with a focus on implementing technology to enrich students' learning experience. These programmes should provide not only technical support to teachers, but perhaps more importantly, situated learning experiences in which they explore and experiment with technology with real students and obtain feedback on their technology integration in authentic classroom settings (Egbert et al. 2002).

In addressing the second research question concerning teachers' perceptions of using technology in their English teaching, the findings indicate that they displayed positive attitudes towards technology use and believed that technology use is a trend and will be a norm in the future, which is consistent with those findings of previous studies (e.g. Huang et al. 2019; Shin and Son 2007). It is noteworthy that the findings also suggest that teachers perceived technology to provide more options and resources for their teaching whilst previous research has yet to regard it as one of the benefits of integrating technology into English language education. It is of global importance to know that teachers have positive perceptions of technology and realise its various affordances for teaching and learning. This could strengthen the theoretical basis for technology integration, which may in turn help to convince teachers of the value of online teaching and learning during the pandemic.

Moreover, the current findings' global importance also lies in that they reveal a misalignment between teachers' perceptions and practices. The relationship between the two has been studied extensively around the globe but has yet to generate conclusive evidence (e.g. Judson 2006; Li and Ni 2011). In this regard, the study 
indicated that although teachers had positive perceptions of technology integration and realised its benefits for students, they used technology primarily for teachercentred activities. Such a misalignment between perceptions and practices can be attributed to the lack of subject-specific training identified as one of the challenges for teachers in this study. Without such training, teachers may suffer from a lack of knowledge about using technology in a constructivist manner (Taghizadeh and Hasani Yourdshahi 2019). It is recommended that the training should provide teachers with an in-depth understanding of the pedagogical rationales and principals of using technology (Comas-Quinn 2011) as well as hands-on experience in practising technology integration into authentic classrooms (Li et al. 2019; Yang and Kuo 2020). They need to understand the pedagogical possibilities of technological tools through a training approach that prioritises teacher self and teacher identity (ComasQuinn 2011).

The findings of this study are critical to the international audience, especially those who mainly see the advantages of technology integration, since it revealed teachers' perceived disadvantages of technology use. Such findings would alert the technology advocates to the potential issues of technology-enhanced teaching and learning, thereby prompting them to be more critical in choosing certain types of technology. In particular, the teachers in the study bemoaned the problem that the use of technology can be distracting and time-consuming, which has also been reported in Chen et al. (2019), England (2007), and Hedayati and Marandi (2014). They perceived using technology to be time-consuming at the beginning but timesaving in the long run, which is in line with the findings of Huang et al. (2019). The interview findings also suggest that it takes time for students to connect to the Internet and learn to use technology. Sometimes students are obsessed with figuring out how to use technology rather than using technology to facilitate their learning. It is interesting to note that such findings are somewhat different from those of previous studies (e.g. Chen 2008; Raman and Yamat 2014) suggesting that it is time-consuming to set up ICT tools, integrate technology into a packed curriculum, and create online learning materials.

With respect to the third research question regarding the challenges and constraints teachers perceived in technology implementation, the present findings indicate that teachers needed to overcome such barriers as unsuitable educational software, insufficient time, the Great Firewall, Internet-related issues, inconsistency of technology equipment across the classrooms, and insufficient technical and pedagogical training in technology implementation. These inhibiting factors for technology integration can largely be subsumed into external challenges (Johnson et al. 2016) or material and finance (van Braak 2001). On the other hand, the internal challenges (e.g. teacher attitudes and beliefs) (Johnson et al. 2016) or human factors (van Braak 2001) are not identified as prominent inhibitors in this study. Such findings are understandable given that teachers had positive perceptions of technology integration. In addition, since the case university under investigation in this study is located in a less developed region and still upgrading its technological infrastructure, it is reasonable to expect that the current research findings are somewhat different from those of Johnson et al. (2016) indicating that much progress has been made to eliminate the external barriers to technology implementation. Indeed, one of the 
contributions of this study lies in its findings about the challenges and constraints for technology implementation, which are important to know for school administrators around the world in making informed decisions about how to support educational practitioners' use of technology for teaching and learning.

In particular, the issue of the Great Firewall is worthy of discussion since it is rarely mentioned in the literature on technology integration (see Mei et al. 2018 for exception) but has great relevance to other regions and societies imposing Internet censorship. The study suggests that the Great Firewall reduced teachers' access to many English-medium websites and resources which can be useful to English language learning in mainland China (Li 2008, 2009). Due to the existence of the virtual firewall system, teachers do not have easy access to English-medium Web 2.0 technologies (e.g. YouTube, Google, Facebook) that are widely used outside mainland China (Mei et al. 2018). This might put English language learners in mainland China in a disadvantaged position in terms of equal access to English learning resources. To address the issues caused by the Great Firewall, the university should provide teachers with free and quality VPNs whilst investing more in developing suitable English learning materials. Indeed, this Internet censorship issue also occurs in other countries like Iran in which website filtering constitutes an occasional obstacle (Hedayati and Marandi 2014). An understanding of this issue could alert policy makers to the potential negative impact of Internet censorship on technology integration.

In terms of the lack of subject-specific training identified by the current study, it can be attributed to school administrators' failure to consult teachers about their needs and weaknesses in technology integration (Okojie et al. 2008). When teachers understand how technology can help them meet the teaching goals in their specific subject content areas, they tend to implement technology in the classroom more frequently (Hughes 2005). It is therefore recommended that the university conduct a needs analysis to truly understand teachers' difficulties in using technology in English teaching so as to provide useful professional development workshops.

\section{Conclusion and limitations}

Drawing on both quantitative and qualitative data, the current findings not only corroborate those of previous research, but also contribute to the understanding of university EFL teachers' technology integration in mainland China whilst addressing a larger issue of technology integration. In particular, this study provides insights into the reasons why teacher-centred use of technology prevails. It also reveals teachers to hold critical opinions on technology integration and discusses the implications for the promotion of teaching innovation and effectiveness. Further, this study deepens the understanding of the challenges (e.g. the Great Firewall) for teachers and provides practical suggestions for facilitating their technology use.

However, two limitations have to be acknowledged. First, regarding research participants, although efforts have been made to include as many EFL teachers at the university as possible, the absence of voice from university administrators and leaders, technical staff as well as students may make it difficult to triangulate EFL 
teachers' responses with other perspectives. Future enquiries should include perspectives from different stakeholders to enrich the findings. Second, given the geographical diversity in mainland China, the findings of this small-scale study may not be inclusive. Further research is warranted to examine Chinese EFL teachers' technology use by involving teachers from various types of universities and different parts of China.

Supplementary Information The online version contains supplementary material available at https://doi. org/10.1007/s43545-021-00223-5.

Authors' contributions The author contributed to the study conception and design. Material preparation, data collection and analysis were performed by the author. The manuscript was written by the author.

Funding The author did not receive support from any organization for the submitted work.

Availability of data and material The datasets generated during and/or analysed during the current study are available from the corresponding author on reasonable request.

\section{Declarations}

Conflicts of interest The author has no relevant financial or non-financial interests to disclose.

Ethical approval The study gained ethics approval from the university prior to data collection.

\section{References}

Alahmari AS (2013) An investigation of Saudi Arabian EFL teachers' engagement with technology. (Doctoral dissertation). Retrieved from Monash University Research Repository. (monash:120645)

Albirini A (2006) Teachers' attitudes toward information and communication technologies: the case of Syrian EFL teachers. Comput Educ 47(4):373-398

Aldukhayel D (2019) Vlogs in L2 listening: EFL learners' and teachers' perceptions. Comput Assist Lang Learn 1-20

Allam M, Elyas T (2016) Perceptions of using social media as an ELT tool among EFL teachers in the Saudi context. Engl Lang Teach 9(7):1-9

Alzubi A (2019) Teachers' perceptions on using smartphones in English as a foreign language context. Res Soc Sci Technol 4(1):92-104

Ashrafzadeh A, Sayadian S (2015) University instructors' concerns and perceptions of technology integration. Comput Hum Behav 49:62-73

Aşık, A., Köse, S., Yangın Ekşi, G., Seferoğlu, G., Pereira, R., \& Ekiert, M. (2019). ICT integration in English language teacher education: Insights from Turkey, Portugal and Poland. Computer Assisted Language Learning, 1-24.

Aydin S (2013) Teachers' perceptions about the use of computers in EFL teaching and learning: the case of Turkey. Comput Assist Lang Learn 26(3):214-233

Bauer J, Kenton J (2005) Toward technology integration in the schools: Why it isn't happening. J Technol Teach Educ 13(4):519-528

Baydas O, Goktas Y (2016) Influential factors on preservice teachers' intentions to use ICT in future lessons. Comput Hum Behav 56:170-178

Bitner N, Bitner J (2002) Integrating technology into the classroom: eight keys to success. J Technol Teach Educ 10(1):95-100

Blake R (2007) New trends in using technology in the language curriculum. Annu Rev Appl Linguist 27(1):76-97 
Braun V, Clarke V (2006) Using thematic analysis in psychology. Qual Res Psychol 3(2):77-101. https:// doi.org/10.1191/1478088706qp063oa

Braun V, Clarke V, Weate P (2016) Using thematic analysis in sport and exercise research. In: Smith B, Sparkes AC (eds) Routledge handbook of qualitative research in sport and exercise. Routledge, London, pp 191-205

Bueno Alastuey MC (2011) Perceived benefits and drawbacks of synchronous voice-based computer-mediated communication in the foreign language classroom. Comput Assist Lang Learn 24(5):419-432

Canals L, Al-Rawashdeh A (2019) Teacher training and teachers' attitudes towards educational technology in the deployment of online English language courses in Jordan. Comput Assist Lang Learn 32(7):639-664

Celik S (2013) Internet-assisted technologies for English language teaching in Turkish universities. Comput Assist Lang Learn 26(5):468-483

Chang, CC, Yan CF, Tseng JS (2012). Perceived convenience in an extended technology acceptance model: mobile technology and English learning for college students. Australas J Educ Technol 28(5):100. https://doi.org/10.14742/ajet.818

Chao CC (2015) Rethinking transfer: learning from call teacher education as consequential transition. Lang Learn Technol 19(1):102-118

Chen M, Flowerdew J, Anthony L (2019) Introducing in-service English language teachers to data-driven learning for academic writing. System 87:102148

Chen YL (2008) A mixed-method study of EFL teachers' Internet use in language instruction. Teach Teach Educ 24(4):1015-1028

Cheok ML, Wong SL (2016) Frog virtual learning environment for Malaysian schools: exploring teachers' experience. In: Huang R, Price K, Jon K (eds) ICT in education in global context. Springer, Singapore, pp 201-209

Chiero T (1997) Teachers' perspectives on factors that affect computer use. J Res Comput Educ 30(2):133-146

Cohen L, Manion L, Morrison K (2013) Research methods in education, 7th edn. Routledge, Oxon

Collins A, Halverson R (2018) Rethinking education in the age of technology: the digital revolution and schooling in America. Teachers College Press, New York

Comas-Quinn A (2011) Learning to teach online or learning to become an online teacher: an exploration of teachers' experiences in a blended learning course. ReCALL 23(3):218-232

Delgado AJ, Wardlow L, McKnight K, Oalley K (2015) Educational technology: a review of the integration, resources, and effectiveness of technology in K-12 classrooms. J Inf Technol Educ 14

DelliCarpini M (2012) Building computer technology skills in TESOL teacher education. Lang Learn Technol 16(2):14-23

Department of Education in China (2001) The basic education curriculum reform outline

Ding ACE, Ottenbreit-Leftwich A, Lu YH, Glazewski K (2019) EFL teachers' pedagogical beliefs and practices with regard to using technology. J Digit Learn Teach Educ 35(1):20-39

Egbert J, Paulus TM, Nakamichi Y (2002) The impact of CALL instruction on classroom computer use: a foundation for rethinking technology in teacher education. Lang Learn Technol 6(3):108-126

England L (2007) Technology applications in English language teaching in Egyptian universities: a developing relationship. Calico J 24(2):381-406

Ertmer PA, Ottenbreit-Leftwich AT, Sadik O, Sendurur E, Sendurur P (2012) Teacher beliefs and technology integration practices: a critical relationship. Comput Educ 59(2):423-435

Fatemi Jahromi SA, Salimi F (2013) Exploring the human element of computer-assisted language learning: an Iranian context. Comput Assist Lang Learn 26(2):158-176

Gao P, Wong AF, Choy D, Wu J (2011) Beginning teachers' understanding performances of technology integration. Asia Pac J Educ 31:211-223

Gruba P, Chau Nguyen NB (2019) Evaluating technology integration in a Vietnamese university language program. Comput Assist Lang Learn 32(5-6):619-637

Gurcay D, Wong B, Chai CS (2013) Turkish and Singaporean pre-service physics teachers' beliefs about teaching and use of technology. Asia Pac Educ Res 22(2):155-162

Hedayati HF, Marandi SS (2014) Iranian EFL teachers' perceptions of the difficulties of implementing CALL. ReCALL 26(3):298-314

Hermans R, Tondeur J, Van Braak J, Valcke M (2008) The impact of primary school teachers' educational beliefs on the classroom use of computers. Comput Educ 51(4):1499-1509 
Hsieh WM, Tsai CC (2017) Taiwanese high school teachers' conceptions of mobile learning. Comput Educ 115:82-95

Hsu L (2016) Examining EFL teachers' technological pedagogical content knowledge and the adoption of mobile-assisted language learning: a partial least square approach. Comput Assist Lang Learn 29(8):1287-1297

$\mathrm{Hu} \mathrm{Z}$, McGrath I (2011) Innovation in higher education in China: are teachers ready to integrate ICT in English language teaching? Technol Pedagog Educ 20(1):41-59

Huang F, Teo T, Zhou M (2019) Factors affecting Chinese English as a foreign language teachers' technology acceptance: a qualitative study. J Educ Comput Res 57(1):83-105

Hughes J (2005) The role of teacher knowledge and learning experiences in forming technology-integrated pedagogy. J Technol Teach Educ 13(2):277-302

Jeong KO (2017) Preparing EFL student teachers with new technologies in the Korean context. Comput Assist Lang Learn 30(6):488-509

Johnson AM, Jacovina ME, Russell DE, Soto CM (2016) Challenges and solutions when using technologies in the classroom. In: Crossley SA, McNamara DS (eds) Adaptive educational technologies for literacy instruction. Taylor \& Francis, New York, pp 13-29

Judson E (2006) How teachers integrate technology and their beliefs about learning: Is there a connection? J Technol Teach Educ 14(3):581-597

Koçoğlu Z (2009) Exploring the technological pedagogical content knowledge of pre-service teachers in language education. Procedia Soc Behav Sci 1(1):2734-2737

Kopcha J (2012) Teachers' perceptions of the barriers to technology integration and practices with technology under situated professional development. Comput Educ 59(4):1109-1121

Kozar O (2016) Perceptions of webcam use by experienced online teachers and learners: a seeming disconnect between research and practice. Comput Assist Lang Learn 29(4):779-789

Kulavuz-Onal D (2018) Technology in instruction. In: Liontas JI, DelliCarpini M (eds) The TESOL encyclopedia of English language teaching. Wiley Blackwell, Hoboken, pp 1-12

Kuru Gönen Sİ (2019) A qualitative study on a situated experience of technology integration: reflections from pre-service teachers and students. Comput Assist Lang Learn 32(3):163-189

Li G, Ni X (2011) Primary EFL teachers' technology use in China: patterns and perceptions. RELC J J Lang Teach Res 42(1):69-85

Li G, Sun Z, Jee Y (2019) The more technology the better? A comparison of teacher-student interaction in high and low technology use elementary EFL classrooms in China. System 84:24-40

Li L (2014) Understanding language teachers' practice with educational technology: a case from China. System 46:105-119

Li Q (2007) Student and teacher views about technology: a tale of two cities. J Res Technol Educ 39(4):377-397

Li Y (2008) The great firewall: The logic of China's administration. 21st Century 4(106):70-87

Li Y (2009) Our great firewall: expression and governance in the era of the internet. Guangxi Normal University Press, Guilin

Liu H, Lin CH, Zhang D (2017) Pedagogical beliefs and attitudes toward information and communication technology: a survey of teachers of English as a foreign language in China. Comput Assist Lang Learn 30(8):745-765

Liu Q, Chao CC (2018) CALL from an ecological perspective: how a teacher perceives affordance and fosters learner agency in a technology-mediated language classroom. ReCALL 30(1):68-87

Manegre M, Sabiri KA (2020) Online language learning using virtual classrooms: an analysis of teacher perceptions. Comput Assist Lang Learn. https://doi.org/10.1080/09588221.2020.1770290

Mei B, Brown GT, Teo T (2018) Toward an understanding of preservice English as a Foreign Language teachers' acceptance of computer-assisted language learning 2.0 in the People's Republic of China. J Educ Comput Res 56(1):74-104

Meskill C, Anthony N, Hilliker-Vanstrander S, Tseng C, You J (2006) CALL: A survey of K-12 ESOL: teacher uses and preferences. TESOL Q 40(2):439-451

Miles M, Huberman AM, Saldaña J (2014) Qualitative data analysis. Sage, Thousand Oaks

Moore Z, Morales B, Carel S (1998) Technology and teaching culture: Results of a state survey of foreign language teachers. Calico J 109-128

Morgana V, Shrestha PN (2018) Investigating students' and teachers' perceptions of using the iPad in an Italian English as a foreign language classroom. Int J Comput-Assist Lang Learn Teach IJCALLT 8(3):29-49 
Mumtaz S (2000) Factors affecting teachers' use of information and communications technology: a review of the literature. Technol Pedagog Educ 9(3):319-342

O'Bryan A, Hegelheimer V (2007) Integrating CALL into the classroom: the role of podcasting in an ESL listening strategies course. ReCALL 19(2):162-180

Okojie MC, Olinzock AA, Adams JH, Okojie-Boulder TC (2008) Technology training dilemma: a diagnostic approach. Int J Instr Media 35(3):261-271

Okojie MC, Olinzock AA, Okojie-Boulder TC (2006) The pedagogy of technology integration. J Technol Stud 32(2):66-71

Pelgrum J (2001) Obstacles to the integration of ICT in education: results from a worldwide educational assessment. Comput Educ 37(2):163-178

Polly D, Rock T (2016) Elementary education teacher candidates' integration of technology in the design of interdisciplinary units. TechTrends 60(4):336-343

Raman K, Yamat H (2014) Barriers teachers face in integrating ICT during English lessons: a case study. Malays Online J Educ Technol 2(3):11-19

Sağlam ALG, Sert S (2012) Perceptions of in-service teachers regarding technology integrated English language teaching. Turk Online J Qual Inquiry 3(3):1-14

Sang G, Valcke M, van Braak J, Tondeur J, Zhu C (2011) Predicting ICT integration into classroom teaching in Chinese primary schools: exploring the complex interplay of teacher-related variables. J Comput Assist Learn 27(2):160-172

Shin HJ, Son JB (2007) EFL teachers' perceptions and perspectives on Internet-assisted language teaching. CALL-EJ Online 8

Siefert B, Kelly K, Yearta L, Oliveira T (2019) Teacher perceptions and use of technology across content areas with linguistically diverse middle school students. J Digit Learn Teach Educ 35(2):107-121

Singh R (2019) Barriers of technology integration in teaching English. Int J Acad Res 1(2):24-37

Sun PP, Mei B (2020) Modeling preservice Chinese-as-a-second/foreign-language teachers' adoption of educational technology: a technology acceptance perspective. Comput Assist Langu Learn. https:// doi.org/10.1080/09588221.2020.1750430

Sung D, Yeh C (2012) Perceptions of using online technology in language education: an interview study with Taiwanese university students. Soc Behav Sci 51:405-410

Taghizadeh M, Hasani Yourdshahi Z (2019) Integrating technology into young learners' classes: language teachers' perceptions. Comput Assist Lang Learn 1-25

Teo T, Huang F, Hoi CKW (2018) Explicating the influences that explain intention to use technology among English teachers in China. Interact Learn Environ 26(4):460-475

Thang SM, Lin LK, Mahmud N, Ismail K, Zabidi NA (2014) Technology integration in the form of digital storytelling: mapping the concerns of four Malaysian ESL instructors. Comput Assist Lang Learn 27(4):311-329

Tondeur J, Pareja Roblin N, van Braak J, Voogt J, Prestridge S (2017) Preparing beginning teachers for technology integration in education: ready for take-off? Technol Pedagog Educ 26(2):157-177

Torsani S (2016) CALL teacher education: language teachers and technology integration. Springer, New York

Trace J, Brown JD, Rodriguez J (2018) How do stakeholder groups' views vary on technology in language learning? CALICO J 35(2):142-161

Türel YK, Johnson TE (2012) Teachers' belief and use of interactive whiteboards for teaching and learning. J Educ Technol Soc 15(1):381-394

van Braak J (2001) Factors influencing the use of computer mediated communication by teachers in secondary schools. Comput Educ 36(1):41-57

Van Olphen M (2013) Perspectives of foreign language preservice teachers on the use of a web-based instructional environment in a methods course. CALICO J 25(1):91-109

Van Praag B, Sanchez HS (2015) Mobile technology in second language classrooms: insights into its uses, pedagogical implications, and teacher beliefs. ReCALL 27(3):288-303

Vongkulluksn VW, Xie K, Bowman MA (2017) The role of value on teachers' internalization of external barriers and externalization of personal beliefs for classroom technology integration. Comput Educ 118:70-81

Wang J (2009) Study on the Matthew effect of higher education founding from Chinese government: from project 211 and project 985 initiatives (in Chinese). Journal of Changchun University of Technology 30(4):57-59

Waycott J, Bennett S, Kennedy G, Dalgarno B, Gray K (2010) Digital divides? Student and staff perceptions of information and communication technologies. Comput Educ 54(4):1202-1211 
Wette R, Barkhuizen G (2009) Teaching the book and educating the person: challenges for university English language teachers in China. Asia Pacific Journal of Education 29(2):195-212

Wilson C, Brereton M, Ploderer B, Sitbon L (2018) MyWord: enhancing engagement, interaction and self-expression with minimally-verbal children on the autism spectrum through a personal audiovisual dictionary. In: Proceedings of the 17th ACM Conference on Interaction Design and Children. ACM, pp. 106-118

Wozney L, Venkatesh V, Abrami P (2006) Implementing computer technologies: teachers' perceptions and practices. J Technol Teach Educ 14(1):173-207

Yang SC, Huang Y (2008) A study of high school English teachers' behavior, concerns and beliefs in integrating information technology into English instruction. Comput Hum Behav 24:1085-1103. https://doi.org/10.1016/j.chb.2007.03.009

Yang YF, Kuo NC (2020) New teaching strategies from student teachers' pedagogical conceptual change in CALL. System 90:102218

Yin R (2009) Case study research: design and methods, 4th edn. Sage, Thousand Oaks

Yunus MM (2007) Malaysian ESL teachers' use of ICT in their classrooms: Expectations and realities. ReCALL 19(1):79-95

Yunus MM, Salehi H, Chenzi C (2012) Integrating social networking tools into ESL writing classroom: strengths and weaknesses. Engl Lang Teach 5(8):42-48 